Acta vet. scand. $1968,9,112-125$.

From the Department of Pathology, National Veterinary Institute and the Department of Veterinary Medicine I, Royal Veterinary College, Stockholm, Sweden.

\title{
LUXATION OF THE CERVICAL SPINAL COLUMN AS A CAUSE OF WOBBLES IN A FOAL
}

\author{
By \\ T. Krunajevic and G. Bergsten
}

A form of ataxia in the horse, called wobbles (in Swedish "slinger"), is characterized by a disturbance of the coordination of the muscular movements, causing the affected animal to show a staggering and unsteady gait. The constant appearance of these characteristic symptoms, well known for more than 60 years, has made the disease an accepted clinical concept. Different opinions as to the etiology and pathogenesis of the disease have been discussed. Dimock \& Errington (1939) observed an "osteoarthritis" of the intervertebral joints of the neck, accompanied, in some cases, by microscopical lesions of the spinal cord. They also found abnormalities in the form of narrowing of the cervical portion of the spinal canal with compression of the cord owing to an abnormally increased mobility of the cervical vertebrae.

Olafson (1942) described abnormally mobile vertebrae and observed hemorrhages in the cord at the sites of certain discs. He also observed degenerative lesions in the white matter with gliosis and thickening of the vascular walls. He believed that the lesions of the spinal cord might be due to the abnormally mobile vertebrae alternatively stretching and compriming the cord.

Jones et al. (1954) reported on examinations of 30 wobblers, ranging from 3 months to 2 years of age. In 14 of these cases there was observed prolapse of a vertebra or a disc with a consequent narrowing of the spinal canal, mostly between $\mathrm{C}_{3}$ and $\mathrm{C}_{4}$. In 16 of the cases, microscopical examination clearly revealed malacia of the spinal cord in spite of the fact that no narrowing could be observed. Osteoarthritis of the joints of the cervical column could be observed in 5 cases. The malacias of the cord showed a marked 
bilateral symmetry. They were localized to the dorsal funiculi cranially of the compression site and caudally of it to the ventral funiculi, on both sides of the ventral median fissure. In most cases lesions could be traced as far backwards as to the region of the 15th thoracic vertebra. In a few cases lesions were observed also in the lumbar spinal cord. In no case nematodes were found in the spinal cord.

Innes \& Pillae (1955) demonstrated larvae of Setaria digitata in the subarachnoidal space with circumscript demyelinization, in a study of wobbles as displayed by horses in Ceylon suffering from a disease known on that island as Kumri.

Steel et al. (1959) examined 11 wobblers ranging from 1 to 3 years of age. They found arthritis of the joints of the cervical vertebrae and degeneration and gliosis of the spinal cord. Narrowing of the spinal canal was observed in 2 cases only. In 1 of these an old fracture with callus formation between $\mathrm{C}_{6}$ and $\mathrm{C}_{7}$, and malacia of the spinal cord, was demonstrated.

Palmer \& Hickman (1960) described a case of wobbles caused by an angioma of the spinal cord between $\mathrm{C}_{6}$ and $\mathrm{C}_{7}$.

Matthias et al. (1965) reported on 4 wobblers, 1 to 2 years old. Microscopical lesions were bilaterally symmetrical malacia in the peripheral portions of the lateral funiculi of the spinal cord and in 1 case in the central portions of the dorsal funiculi, cranially to the 3rd-4th cervical vertebrae. Caudally to this site, there were lesions in the ventral funiculi symmetrically on both sides of the ventral median fissure. The lesions decreased successively in the caudal direction and could not be demonstrated further backwards than in the region of the 1st lumbar vertebra.

Laurie (1966) reported on a case of wobbles with compression of the spinal cord due to luxuriant bone formation in $\mathrm{C}_{3}$.

Fraser \& Palmer (1967) gave an account of examinations of 26 atactic horses, divided into 3 groups. The first group, which was considered as comprising typical wobblers, was characterized by primary lesions of the cervical spinal cord with secondary lesions in both the cranial and caudal direction. The horses showed the same type of ataxia, and with few exceptions they were all stallions from 4 months to 3 years of age. In 2 out of 3 cases where the cervical intervertebral joints were examined, osteoarthritis and osteoarthrosis, respectively, were demonstrated. Subluxation of amphiarthrodial joints of the cervical column with subsequent narrowing of the spinal canal was 
observed in 3 instances. These 5 cases were the only ones where the cause of the primary lesion was revealed. At the site of the primary lesion there was observed diffuse malacia of the white matter in all instances. In the gray matter, lesions were observed in 4 cases only (slight proliferation of the microglia in 2 instances, and severe lesions in the form of total loss of neurons, proliferation of microglia, and perivascular fibrosis in 2 instances). Secondary lesions, varying in intensity, were present in the white matter only. There was a special pattern in the situation of malacia common to all the instances. Cranially to the primary lesion the lesions had a symmetrically bilateral position in the peripheral portions of the lateral funiculi. A few cases also displayed slight lesions in the dorsal funiculi. The lesions could be traced as far cranially as into the medulla oblongata and the pedunculi cerebelli inferiori and superiori. In the caudal direction from the primary lesion the lesions could be followed mostly as far back as into the lumbar spinal cord. Even here, the lesions showed bilateral symmetry but were situated in the ventral funiculi next to the ventral median fissure and the central portions of the lateral funiculi. In the second group all cases were brought together in which the symptoms could be explained by a definite morphological diagnosis, such as cerebellary hypoplasia, cerebellary nematodiasis, and compression of the spinal cord due to varying causes such as local bone neoplasia, hematoma, vertebral fracture, and deforming arthritis of intervertebral joints. The lesions of the spinal cord resembled those in the first group.

The third group comprised cases which, owing to inadequate documentation, could not be referred to either of the other groups.

\section{CLINICAL OBSERVATIONS}

On August 15, 1966 a 3-month-old stallion foal was submitted to the medical clinic with a history of wobbles. It had been born without complications after a pregnancy of normal duration. According to the manager it rose without aid and displayed no signs of disturbed locomotion. At 1 week of age the foal got a navel infection, which, however, healed after local penicillin treatment. At 6 weeks it got fever, cough and a purulent nasal discharge, and was given antibiotic treatment for 10 days. After having recovered clinically, the foal was let out on range. In the beginning of August it was observed that the foal had a stiff and staggering gait in the hind legs. The veterinarian consulted found 
the foal to be coughing and having a rise in temperature $\left(40.5^{\circ}\right)$. He also observed friction rubs at lung auscultation. The foal was removed from the pasture and was subject to treatment with daily penicillin administration and vitamin E-injections.

The foal's state of health improved during the first week of treatment. The fever subsided and the cough decreased. Even the wobbling seemed to subside. After the lapse of another few days, however, the foal got weaker again and the wobbling increased.

On arrival at the clinic the foal showed a moderately depressed general condition. Temperature was normal and so were palpable lymph glands and visible mucous membranes. The foal lay flat on its side and was unable to rise. If brought to its feet it was able to stand and to take a few steps. It thereby stagged and sometimes knuckled on one or both hind legs. Reflexes and cutaneous sensibility were normal. Cytological examination of cerebrospinal fluid showed nothing abnormal, but bacteriological examination revealed the presence of $\alpha$-hemolytic cocci. Therefore, chloromycetin treatment was begun. During the first few weeks in the clinic the wobbling increased so that the foal had great difficulties in standing without support. Trying to walk, it fell repeatedly and thereby contracted a wound in the nuchal region.

Renewed bacteriological examination of the cerebro-spinal fluid after some 3 weeks of hospitalization showed no change in earlier findings. Electrophoretic examination showed increased values for total protein content.

At this point the clinical status of the foal showed a tendency towards gradual improvement, and on September 15 it was able to rise and move about relatively freely. It was still wobbling, though, and these symptoms were accentuated when the foal was made to turn or walk backwards. It was no longer observed to knuckle. If its head was raised rapidly it regularly fell over on its back. The clinical improvement observed, though, did not last long. After a few days the foal resumed its unability to rise. When brought to its feet it showed increasing difficulties in remaining standing without support, and it was therefore decided to regard the prognosis as fairly unfavourable. The foal was slaughtered on September 28. A sample of cerebrospinal fluid collected at slaughter was still positive for cocci. Leukocyte count had increased considerably as compared to earlier examinations, and total protein content was still high. 


\section{PATHO-ANATOMICAL LESIONS}

The foal was killed by intravenous injection of a $6 \%$ pentobarbital sodium solution (Mebumal sodium) and immediately afterwards submitted for post-mortem examination. The spinal column was cut open from the dorsal side by removing the vertebral arches. After removal of the spinal cord, the column was split sagittally by sawing. Brain and marrow cord were fixed in a $10 \%$ aqueous solution of formaldehyde and embedded in paraffin for sectioning and histological examination. The following staining techniques were used: Hematoxylin-eosin, v. Gieson, PAS, diastas-PAS, Luxol Fast Blue, and Holmes silver nitrate stain according to Margolis \& Pickett (1956).

Gross examination revealed a somewhat poor nutritional state. Over the nuchal ridge there was a swollen area half the size of a man's palm. In this area there was a pea-sized cutaneous granulating ulcer. There was a subcutaneous infiltrate consisting of a chronic granulation tissue, $10 \mathrm{~mm}$ thick and exhibiting focal hemorrhages.

At the branching site of the A. ileo-caeco-colica from the A. mesenterica cranialis there was a fresh verminous endarteritis. Small parasitic spots were observed disseminated in the liver.

The cranial part of the 3rd cervical vertebra was dislocated in the dorsal direction and was immovably connected with the 2nd vertebra, with which it formed an angle of $120^{\circ}$. No rupture or other defect could be observed in the disc. There was, however, a malformation of the cranial epiphysis. The epiphysis line, running dorsally in the normal way, approached the closing plate some $10 \mathrm{~mm}$ from the ventral attachment of the disc (Fig. 1). The cranial portion of the vertebra was notably thin. Owing to the luxation described there was a marked narrowing of the spinal canal with compression of the cord. The latter presented a conspicuous strangulation furrow. In the 4 th disc there was a small hemorrhage. There were no lesions of the intervertebral joints.

A total number of 303 specimens of Parascaris equorum were found in the intestines.

At microscopical examination the most severe lesions were observed to be a diffuse demyelinization and disintegration of the axis cylinders in the white matter at the site of compression. Thus, myelomalacias of varying sizes had resulted (Figs. 5-6). The microglia showed hypertrophy and proliferation and formed 


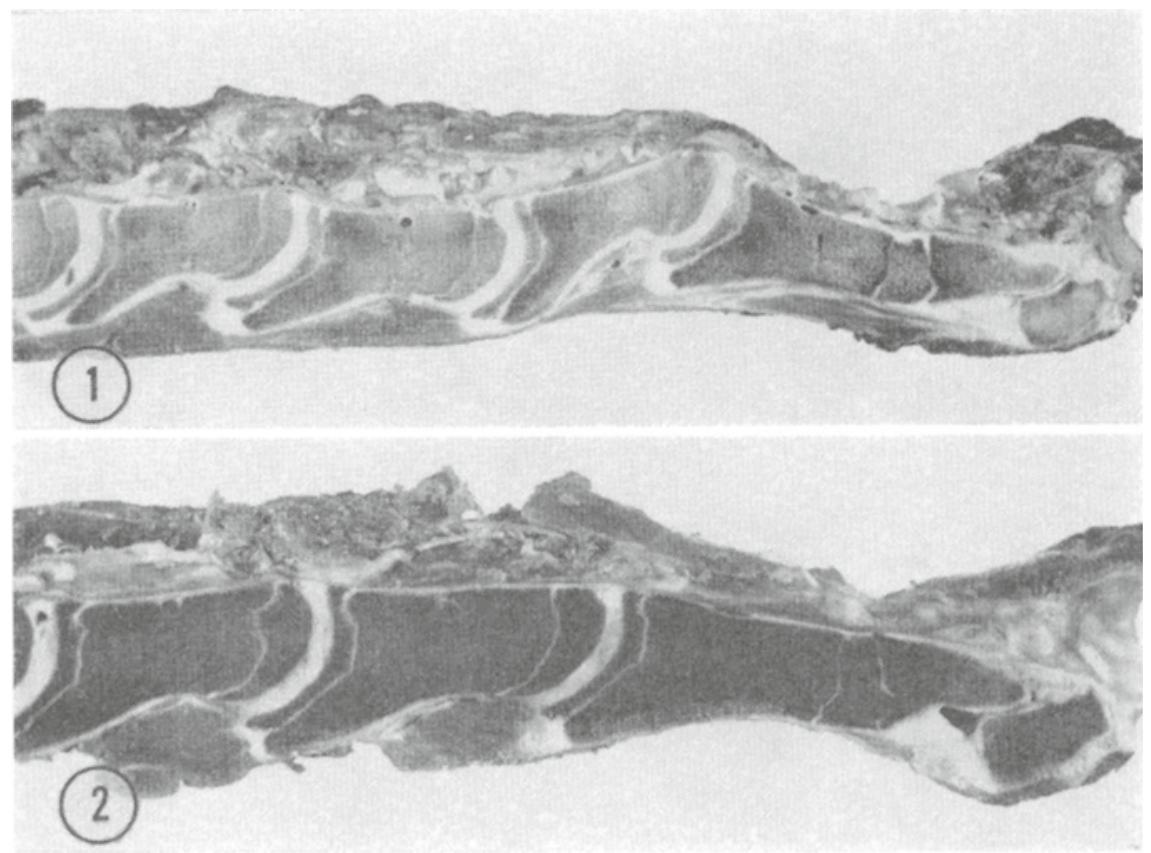

F i g u re 1. Sagittal section through a part of the cervical spine with the vertebral arches and the spinal cord removed demonstrating:

a) Luxation of the anterior extremity of the body of the 3rd cervical vertebra associated with stenosis of the spinal canal. Note deformity of cranial epiphysis of the $\mathrm{C}_{3}$.

b) Focus of disintegration and dark red discolouration in the 4th cervical disc.

Figure 2. Cervical spine of normal control (8-month-old colt).

foci of varying sizes. There was focal demyelinization and reduction in number of ganglion cells in the gray matter (Fig. 7). Remaining ganglion cells were pycnotic or lytic. In both gray and white matter the vascular walls showed a perivascular fibrosis (Figs. 5 and 7) and small fresh hemorrhages.

On both sides of the compression site there were severe demyelinization, swelling and disintegration of axis cylinders, and diffuse gliosis (Figs. 3 and 4 ). These lesions were clearly bilaterally symmetrical. Cranially of the compression site, they were situated in the peripheral parts of the lateral funiculi and in the central parts of the dorsal funiculi. In the medulla oblongata lesions were observed in the first mentioned site only. Caudally of the compression site the lesions were found in the ventral 


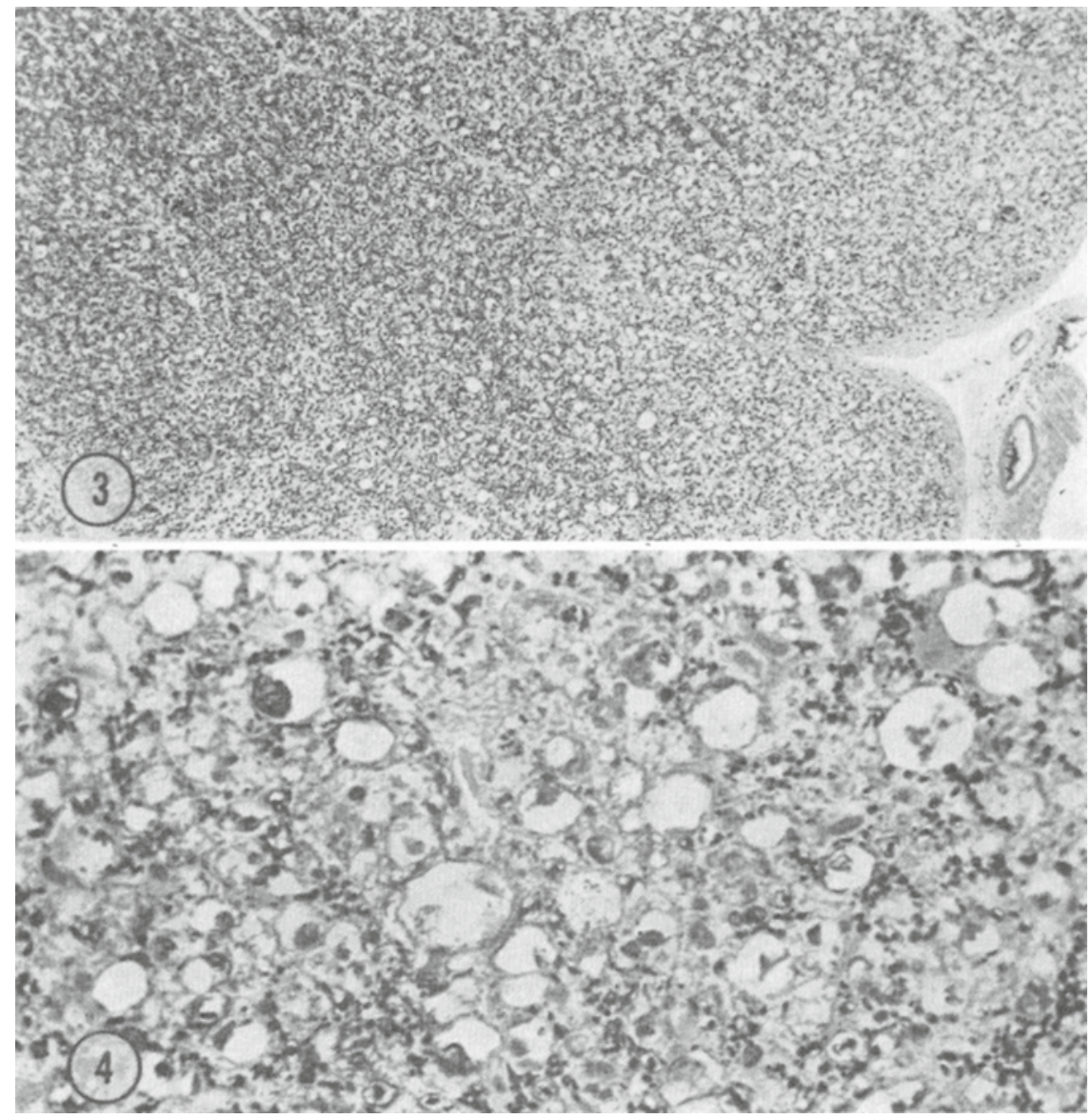

Figure 3. Demyelinization of the lateral funiculus of the cervical spinal cord ahead of stenosis. Note the decrease of changes to the centre (to the left). Luxol fast blue $50 \times$.

Fig u re 4. Field of Fig. 3 showing ballooning and destruction of myelin sheaths. Note the dropping out of axis cylinders and distortion of most of the remaining ones. $300 \times$.

funiculi next to the ventral median fissure, and in the central portions of the lateral funiculi. The distribution of the spinal cord lesions is seen from Fig. 8. Occasional hemorrhages were observed in both gray and white matter. The nerve cells showed no lesions. The spinal nerves displayed demyelinization of varying intensity. There were several glia cells containing a PASpositive diastase resistent homogeneous material in their cyto- 


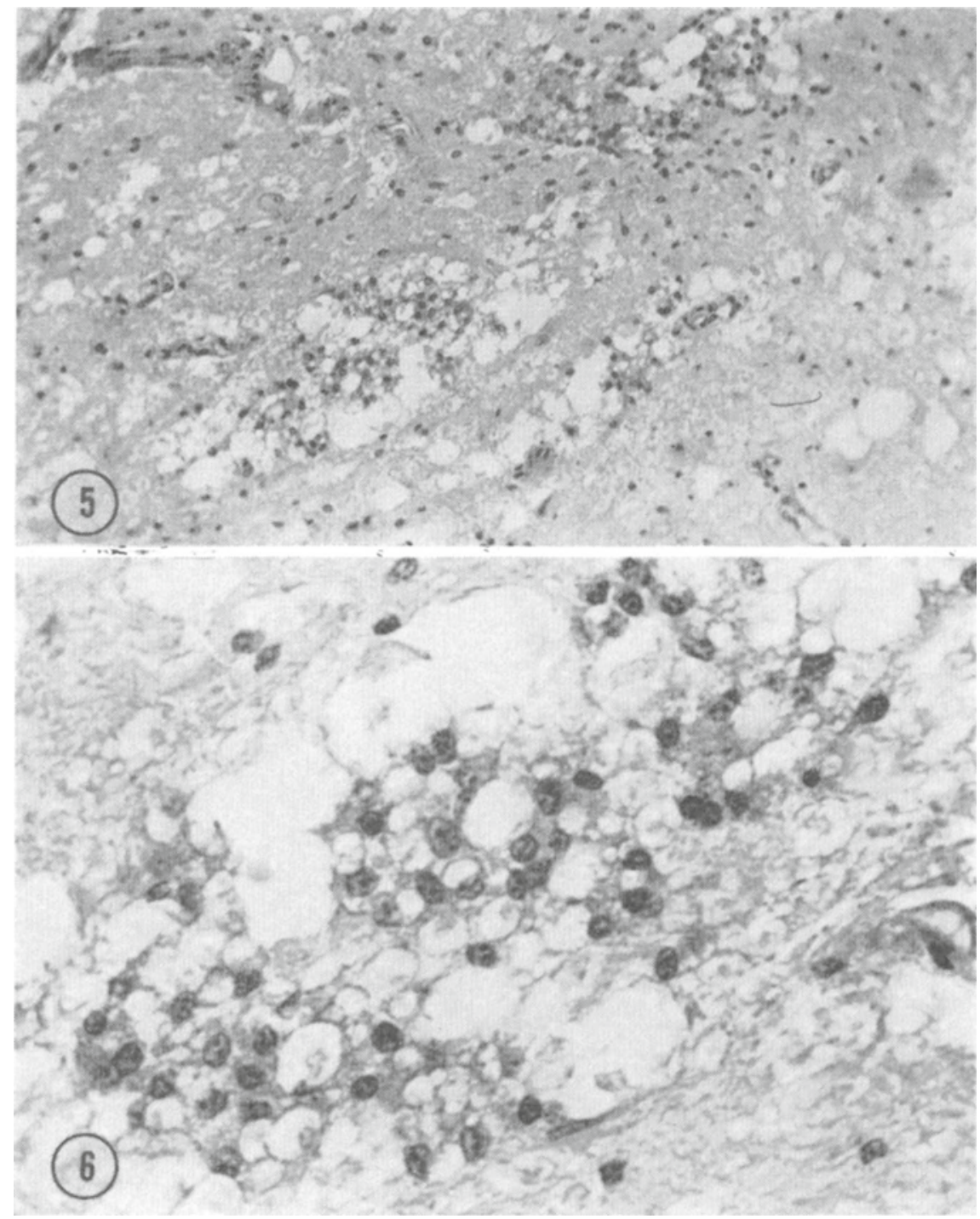

F i g u r e 5. Cervical spinal cord, white matter, at the level of stenosis, demonstrating destruction of tissue with gliosis. Note the thickening of blood vessels. Luxol fast blue $150 \times$.

Figure 6. Field of Fig. 5 demonstrating marked necrosis of tissue with accumulation of glia cells. $500 \times$.

plasm. In the lumbar spinal cord there was observed a predominantly diffuse swelling of the myelin sheaths, mainly in the lateral and ventral funiculi. Demyelinization occurred occasion- 


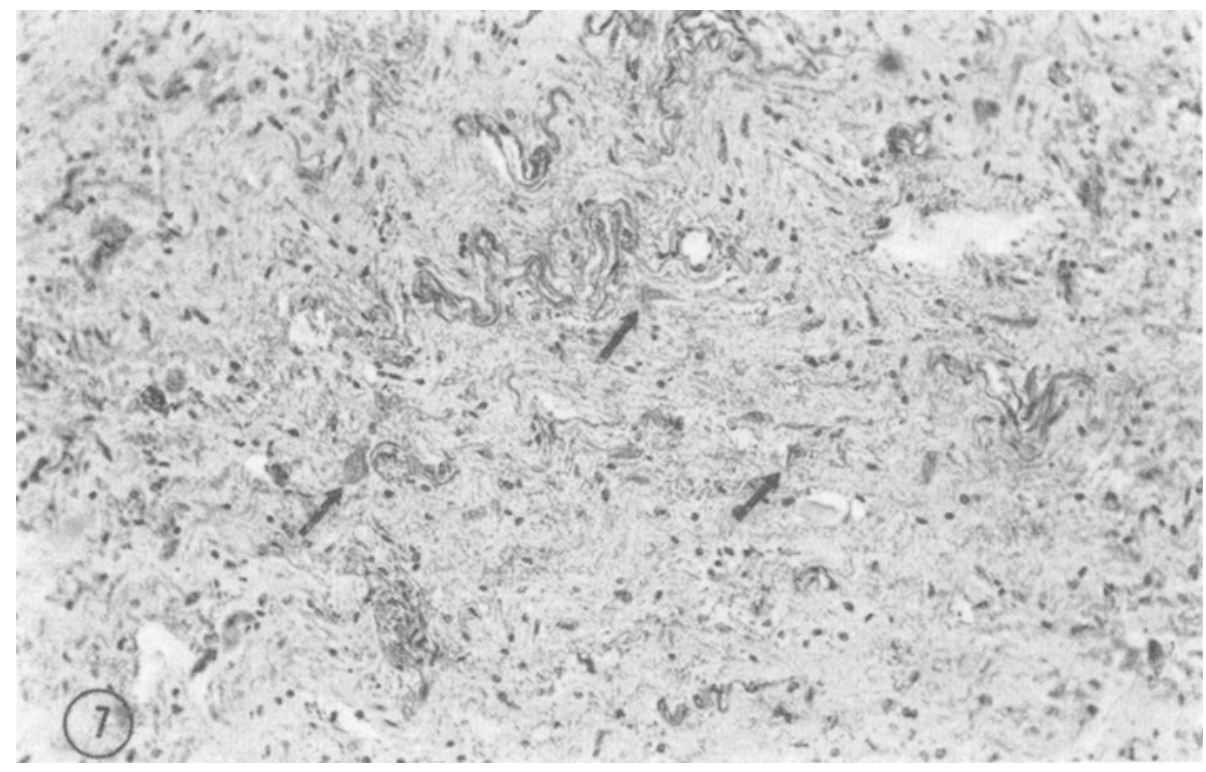

F i g u r e 7. Cervical spinal cord (same section as Fig. 5), grey matter, showing loss of all but a few ganglion cells. Those remaining are degenerate (arrows). Note the pronounced thickening of blood vessels. $150 \times$.

ally only. No lesions were observed in the cauda equina. In the brain, there were no lesions observed except a few fresh hemorrhages in the thalamus.

The malformed epiphysis showed no microscopical lesions. The hemorrhage observed in the 4 th cervical disc was found to be in the nucleus pulposus and had no apparent communication with adjacent structures.

\section{DISCUSSION}

The present case clinically coincides well with the descriptions of wobblers given in the literature. A majority of workers in this field have demonstrated spinal lesions with narrowing of the spinal canal and a consequent compression of the spinal cord as the cause of this ataxia in young horses.

In the present case the cause was a luxation. This is a lesion, which, to our knowledge, has not so far been reported in any of the numerous descriptions of wobbles. Subluxation of amphi- 

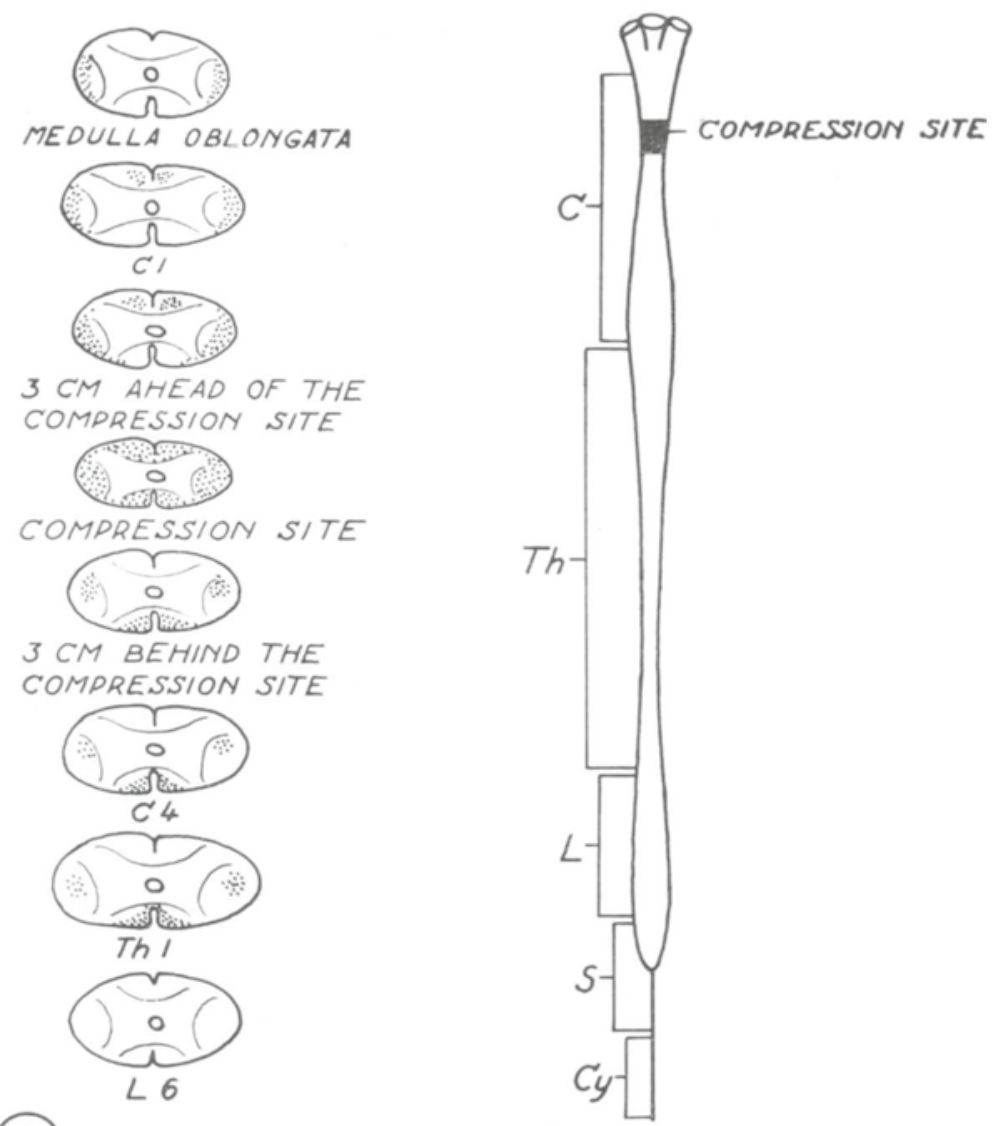

8.

Figure 8. Diagram showing distribution and extent of changes in the spinal cord.

arthrodial joints of the cervical column was described by, inter alia, Olafson (1942) and Fraser \& Palmer (1967).

The latter lesion arises as a result of flexion of the neck and disappears at extension. In our case we were dealing with a permanent static deformity which was not corrected by extension.

The microscopical lesions found in the spinal cord coincide with those described by other workers (Jones et al. 1954; Matthias et al. 1965; Fraser \& Palmer). The reactive lesions at the compression site with severe fibrosis of vascular walls and gliosis suggest that the lesion of the cord has been present for considerable time. This interpretation is corroborated by the history 


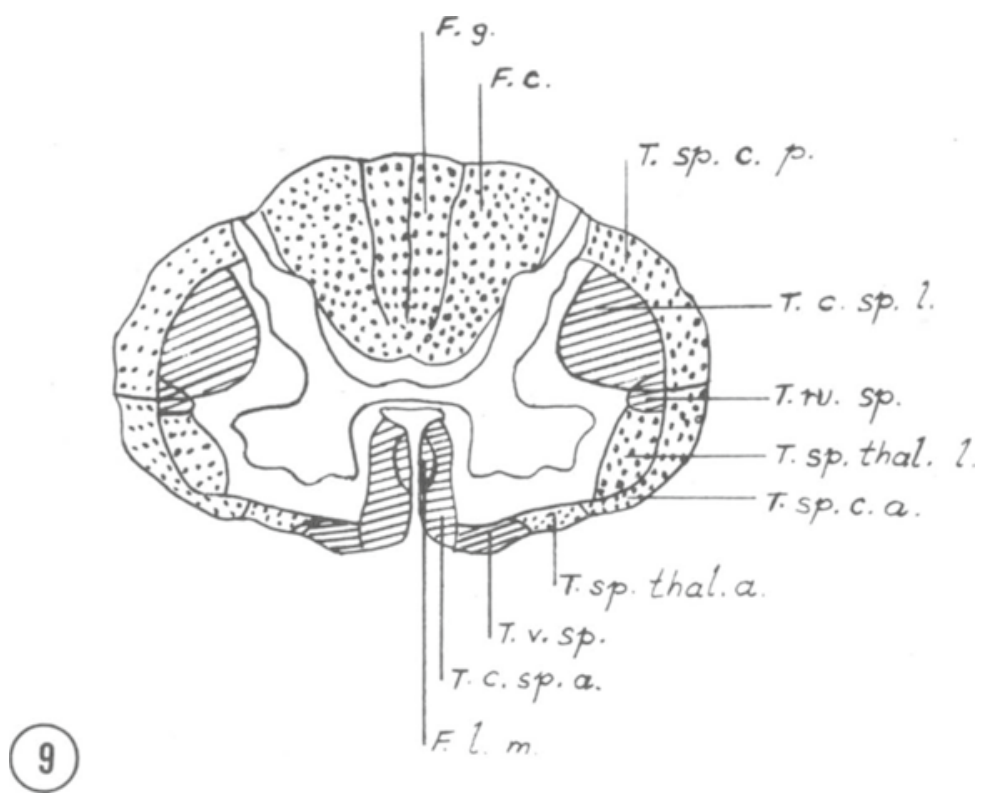

F i g u r e 9. Transverse section of the human spinal cord at the level of $\mathrm{C}_{6}$ demonstrating descending (lined) and ascending (dotted) tractes. F. g. Fasciculus gracilis; F. c. Fasciculus cuneatus; T. sp. c. p. Tractus spinocerebellaris posterior; T. c. sp. l. Tractus corticospinalis lateralis; T. ru. sp. Tractus rubrospinalis; T. sp. thal. 1 . Tractus spinothalamicus lateralis; T. sp. c. a. Tractus spinocerebellaris anterior; T. sp. thal. a. Tractus spinothalamicus anterior; T. v. sp. Tractus vestibulospinalis; T. c. sp. a. Tractus corticospinalis anterior; F. l. m. Fasciculus longitudinalis medialis. (According to Petrén 1958).

of symptoms of ataxia for approximately 2 months. Cranially of the compression site the lesions have been found in the fasciculus gracilis (Goll's cord) and the fasciculus cuneatus (Burdach's cord), and in both tractus spinocerebellaris. Caudally of the compression site, in contrast, the lesions have been found in the tractus corticospinalis anterior, the tractus vestibulospinalis, the fasciculus longitudinalis medialis, and in the tractus corticospinalis lateralis and the tractus rubrospinalis. The fasciculus gracilis and the fasciculus cuneatus lead proprioceptive impulses from the caudal roots of the spinal nerves to the cerebrum. The former consists of the neurites of the sacral, lumbar, and thoracic nerves, and leads impulses from the lower part of the body. The latter tract consists of the neurites from the cranial thoracic and the cervical nerves and leads impulses from the upper part of the body. Through the tractus spinocerebellaris anterior et posterior 
proprioceptive impulses are conducted from the caudal roots of the spinal nerves to the cerebellum. The tractus corticospinalis anterior et lateralis consist of neurites emerging from the cerebral cortex and extend to the motor cells of the cranial spinal horns. They lead impulses to striated muscles and thus coordinate the voluntary movements.

Both the tractus vestibulospinalis and the fasciculus longitudinalis medialis originate from the vestibular nuclei situated in the area vestibularis which, in turn, communicates with the pars vestibularis of the VIII. brain nerve (N. stato-acusticus) and the cerebellum. Thus, they are most evidently important in the maintenance of equilibrium. The tractus vestibularis possesses neurites joining in synapses with the motor cells of the cranial horns and extends as far as into the sacral region. This tract subordinates the muscles of the neck and the body under the influence of the sense of balance and the coordinating impulses from the cerebellum.

The description above applies to man, in which these nerve tracts have been most thoroughly explored. There seems, however, to be extensive analogies between man and other mammals, and the most important difference seems to be in the development of the tractus rubrospinalis. The latter is strongly reduced in primates but is well developed in other animals.

The PAS-positive diastase resistent material found in glia cells surrounding foci of malacia are most probably fragments of phagocytized myelin sheaths. When situated freely, myelin fragments are stained in the same manner.

It has not been possible to verify the cause of the luxation observed in the present case. It may be assumed to have been a congenital defect or the result of a traumatic injury during early life. In either case, the clinical symptoms may be assumed not to have appeared until sceletal growth has induced a marked narrowing of the spinal canal.

It is difficult to explain the presence of a fresh hemorrhage in the nucleus pulposus of the 4 th cervical disc, as the intervertebral disc is lacking in blood vessels, and nerves. Even though no communication has been observed between the hemorrhage and the vessels of adjacent vertebrae, the blood must be assumed to originate from the surroundings of the disc. The finding of a hemorrhage in this area may be taken to support the suspicion of a traumatic cause. 


\section{REFERENCES}

Dimock, W. W. \& B. J. Errington: Incoordination of equidae: "Wobblers". J. Amer. vet. med. Ass. 1939, 95, 261-267.

Fraser, H.\& A. C. Palmer: Equine incoordination and wobbler disease of young horses. Vet. Rec. 1967, 80, 338-355.

Innes, J. R. M. \& P. Pillae: Kumri - so-called lumbar paralysis - of horses in Ceylon (India and Burma) and its identification with cerebrospinal nematodiasis. Brit. vet. J. 1955, 111, 223-235.

Jones, T. C., E. R. Doll \& R. G. Brown: The pathology of equine incoordination. Proc. Amer. vet. med. Ass., 91st ann. Meeting 1954, $139-149$.

Laurie, T.: Equine wobbler syndrome. Iowa State Univ. Veterinarian 1966, 28, 25-27.

Margolis, G. \& J. P. Pickett: New applications of the Luxol Fast Blue Myelin stain. Lab. Invest. 1956, 5, 459-474.

Matthias, D., O. Dietz \& R. Rechenberg: Zur Klinik und Pathologie der Spinalen Ataxie der Fohlen. Arch. exp. Vet.-Med. 1965, 19, 43-72.

Olafson, P.: "Wobblers" compared with ataxic (swingback) lambs. Cornell Vet. 1942, 32, 301-314.

Palmer, A. C. \& J. Hickman: Ataxia in a horse due to an angioma of the spinal cord. Vet. Rec. 1960, 72, 611-613.

Petrén, T.: Lärobok i Anatomi. III. Nervsystemet. Stockholm 1958, 83-114.

Steel, J. D., J. H. Whittem \& D. R. Hutchins: Equine sensory ataxia (wobbles). Clinical and pathological observations on Australian cases. Aust. vet. J. 1959, 35, 442-449.

\section{SUMMARY}

The clinical and pathological details of a case of ataxia in a 3 -month-old colt are described. A marked protrusion into the vertebral canal of the body of the 3 rd cervical vertebra was observed. $\mathrm{C}_{3}$ and $\mathrm{C}_{2}$ were immovably joined so that the deformity could not be corrected by extension of the spinal column at this point. There was a compression of the spinal cord corresponding to the protrusion.

The cause of this luxation could not be established. It may be assumed that the distortion was congenital, or caused by trauma at an early stage and that clinical symptoms could be observed only when a marked narrowing of the vertebral canal had arisen as a result of the growth of the sceleton.

Histopathological examination of the spinal cord at the site of the compression revealed severe malacia with marked gliosis and perivascular fibrosis involving dorsal, lateral and ventral white funiculi and gray matter. Secondary changes were observed ahead of and behind the primary lesion. Distribution and extent of the lesions are shown graphically. In principle, clinical manifestation and pathological findings seem to be very similar to those which are observed in the disease described in the USA and other countries as "wobbles". 


\section{ZUSAMMENFASSUNG}

Eine Luxation in der Halswirbelsäule als Ursache von Ataxie beim Fohlen.

Klinische Symptome und pathologisch-anatomische Veränderungen eines Fall von spinaler Ataxie bei einem drei Monate alten Fohlen werden beschrieben. Eine markierte Vorstülpung des dritten Halswirbels in den Rückenmarkkanal wurde beobachtet. Der dritte und zweite Halswirbel waren starr miteinander verbunden, so dass die Missbildung durch Streckung der Wirbelsäule nicht korrigiert werden konnte. Die Luxation hatte eine ausgeprägte Verdrängung des Rückenmarkkanales mit Kompression des Rückenmarkes zufolge. Die Ursache dieser Luxation konnte nicht festgestellt werden. Es dürfte wahrscheinlich sein, dass dieser Defekt entweder angeboren oder das Ergebnis eines in der frühen Phase der Entwicklung erlittenen Traumas war und dass die klinischen Symptome erst auftraten, nachdem eine stärkere Verdrängung des Rückenmarkkanales durch die weitere Entwicklung des Skelettes zustande gekommen war. Bei der histologischen Untersuchung des Rückenmarkes an der Kompressionsstelle wurde eine starke Malazie mit Gliose sowie perivaskuläre Fibrose in den dorsalen, lateralen und ventralen Funiculi und in der grauen Substanz beobachtet. Sekundäre Veränderungen waren kranial und kaudal vom Primärschaden sichtbar. Sowohl klinisch als auch patologisch-anatomisch zeigen die Veränderungen Ähnlichkeit mit den in der angelsächsischen Literatur beschriebenen Fällen von sogenannten „Wobbles“.

\section{SAMMANFATTNING}

Luxation $i$ halskotpelaren som orsak till slinger hos föl.

Kliniska och patolog-anatomiska förändringar vid ett fall av spinal ataxi (slinger) hos ett 3 månader gammalt föl beskrives.

Tredje halskotan var förskjuten dorsalt i sin kraniala del och var orörligt förenad med andra halskotan, så att-missbildningen ej kunde korrigeras genom sträckning av halskotpelaren. Luxationen hade orsakat en markerad förträngning av ryggmärgskanalen med kompression av ryggmärgen.

Orsaken till den i detta fall iakttagna luxationen har ej kunnat fastställas. Det får anses som sannolikt att denna defekt varit antingen medfödd eller ett resultat av trauma tidigt i livet och att de kliniska symtomen debuterat först när genom skelettillväxten en markerad förträngning av ryggmärgskanalen uppkommit. Vid histologisk undersökning av ryggmärgen vid kompressionsstället iakttogs markered malaci med glios och perivaskulär fibros i dorsala, laterala och ventrala funiculi och i grå substansen. Sekundära förändringar observerades kranialt och kaudalt om primärskadan.

Såväl kliniska bilden som patologisk-anatomiska förändringarna visar principiella likheter med i litteraturen beskrivna fall av s.k. ,wobbles“.

(Received January 18, 1968). 